Chapman University

Chapman University Digital Commons

Education Faculty Articles and Research

College of Educational Studies

$11-2016$

\title{
Increasing Engagement of Students with Learning Disabilities in Mathematical Problem-Solving and Discussion
}

\author{
Rachel Lambert \\ Chapman University, lambertr@chapman.edu \\ Trisha Sugita \\ Chapman University, nishimur@chapman.edu
}

Follow this and additional works at: http://digitalcommons.chapman.edu/education_articles

Part of the Curriculum and Instruction Commons, Disability and Equity in Education Commons, Educational Sociology Commons, Science and Mathematics Education Commons, and the Special Education and Teaching Commons

\section{Recommended Citation}

Lambert, R., \& Sugita, T. (2016). Increasing engagement of students with learning disabilities in mathematical problem-solving and discussion. Support for Learning, 31, 347-366. doi:10.1111/1467-9604.12142

This Article is brought to you for free and open access by the College of Educational Studies at Chapman University Digital Commons. It has been accepted for inclusion in Education Faculty Articles and Research by an authorized administrator of Chapman University Digital Commons. For more

information, please contact laughtin@chapman.edu. 


\section{Increasing Engagement of Students with Learning Disabilities in Mathematical Problem-Solving and Discussion}

\section{Comments}

This is the accepted version of the following article:

Lambert, R., \& Sugita, T. (2016). Increasing engagement of students with learning disabilities in mathematical problem-solving and discussion. Support for Learning, 31: 347-366. doi:10.1111/ $1467-9604.12142$

which has been published in final form at DOI: 10.1111/1467-9604.12142. This article may be used for noncommercial purposes in accordance with Wiley Terms and Conditions for Self-Archiving.

\section{Copyright}

Wiley 


\title{
Increasing engagement of students with learning disabilities in mathematical problem-solving and discussion
}

\author{
Rachel Lambert, Ph.D. \\ Chapman University \\ One University Dr. \\ Orange, CA. 92866 \\ Trisha Sugita, Ph.D. \\ Chapman University \\ One University Dr. \\ Orange, CA. 92866
}

\section{Citation:}

Lambert, R., \& Sugita, T. (2016). Increasing engagement of students with learning disabilities in mathematical problem-solving and discussion. Support for Learning, Advance online publication. 


\section{Increasing engagement of students with learning disabilities in mathematical problem-solving and discussion}

Engagement in problem-solving and mathematical discussion is critical for learning mathematics. This research review describes a gap in the literature surrounding engagement of students with Learning Disabilities in standards-based mathematical classrooms. Taking a sociocultural view of engagement as participation in mathematical practices, this review found that students with LD were supported towards equal engagement in standards-based mathematics through multi-modal curriculum, consistent routines for problem-solving, and teachers trained in Mathematical Knowledge for Teaching. Using this small set of studies (7), we identify the need to deepen the engagement of students with LD in mathematical problem-solving and discussion. This review concludes with implications for teaching and learning.

Keywords: mathematics education, special education, learning disabilities, mathematical practices, Mathematical Knowledge for Teaching 


\section{Increasing engagement of students with learning disabilities in mathematical problem-solving and discussion}

Current educational reform in the United States calls for all students to become proficient in $21^{\text {st }}$ century skills in order to increase student participation in emerging fields such as Science, Technology, Engineering, and Mathematics (STEM). Currently students with Learning Disabilities (LD) are underrepresented in STEM fields at the undergraduate level (Dunn, Rabren, Taylor \& Dotson, 2012). We call attention to this disparity, and suggest one possible culprit: limited engagement in problem-solving mathematics curriculum for students with LD. For students to develop flexible problemsolving skills in mathematics, they must have considerable experience engaging with challenging mathematical problems. Literature in mathematics education found that when students are engaged in problem solving and mathematical discussion rather than memorization, they become are equally efficient in calculation and better prepared to transfer knowledge and problem solve (Boaler 1997; Boaler \& Staples, 2008; Silver \& Stein, 1996).

Yet some studies have found that students with LD are less engaged in problemsolving and mathematical discussion than nondisabled peers in standards-based mathematics classrooms (Baxter, Woodward, \& Olson, 2001; Bottge, Heinrichs, Mehta, \& Hung, 2002). In this literature review, we will present findings of limited engagement, as well as additional studies that demonstrate that teachers can positively impact the engagement of students with LD in mathematical problem-solving and discussion. We will provide evidence that students with LD are able to successfully participate in standards-based mathematics instruction when provided specific instructional supports. 
While the literature is limited in scope due to the small number of studies available, the studies profiled in this literature review provide a blueprint for expanding this critical strand of research.

This review defines the term engagement not simply as on-task behavior, but as engagement in the practices that define mathematical activity such as discourse and problem solving (Nasir \& Hand, 2006). Building proficiency in mathematics for all learners entails sustained and deep engagement in practices that include problem solving, reasoning, and critique. These practices are also known as the Standards for Mathematical Practices in the Common Core State Standards for Mathematics adopted by many states in the United States (2010). Engagement in these mathematical practices had a positive correlation with increased achievement in mathematics (e.g., Ing, Webb Franke, Turrou, Wog, Shin, \& Fernandez, 2015; Webb, Franke, Ing, Wong, Fernandez, Shin, \& Turrou, 2014).

In reviewing the special education literature on math instruction, special education classrooms have been primarily dominated by computational practices (e.g, math facts), rather than inquiry and problem solving offering students with LD fewer opportunities to access standards-based mathematical practices and conceptual inquiry (Kurz, Elliott, Wehby, \& Smithson, 2010; Woodward \& Montague, 2002). For example, Jackson and Neel (2006) found that students in general education classrooms spent significantly more time engaged in conceptual work in mathematics $(61 \%$ observed time), while students in a special education segregated setting spent far less time engaging in conceptual mathematics ( $19 \%$ of observed time). 
Even when students with LD are included in mathematics instruction focused on concepts, two studies have found that students with LD were less engaged than their nondisabled peers. In one study, students with LD included in general education classrooms were called on fewer times than other students, and were less engaged in small group work (Bottge, Heinrichs, Mehta, \& Hung, 2002). In another study, students with LD, who were grouped in a category that included students with low achievement in mathematics, were less likely to be called on in whole group discussion, and were more likely to be engaged in non-mathematical tasks such as material management during small group work (Baxter, Woodward, \& Olson, 2001). The disparity in engagement has led the field to explore ways to increase engagement and engagement for students with LD in standards-based mathematics (Baxter, Woodward, \& Olson, 2005; Bottge, Rueda, Serlin, Hung, \& Kwon, 2007). The purpose of this literature review is to identify research that attempts to deepen the engagement of students with LD in meaningful mathematical practices.

\section{Conceptual Framework}

This section begins with research on the notion of engagement in mathematics education. Multiple perspectives on learning disabilities are explored, and finally the research on mathematics for students with learning disabilities in special education.

\section{Mathematics Education}

A sociocultural perspective on engagement in mathematics understands learning as developing into the practices that characterize expert behavior (Forman, 1996; Lave \& Wenger, 1991; Nasir \& Hand, 2008). In mathematics, these practices include student's perseverance in problem solving, engaging in quantitative reasoning, and critiquing the 
mathematical thinking of others. These practices are the first three Mathematical Practice Standards of the Common Core Standards (2010). Studies in engagement in mathematics from a sociocultural perspective analyze engagement and discourse in whole and small group learning, while tracking how learners take up these mathematical practices (e.g., Empson, 2003; Gresalfi, Martin, Hand, \& Greeno, 2009).

\section{Student Engagement}

Student engagement matters in learning mathematics. Studies of engagement in schools have found that the more students participate, the more they learn in all content areas (Ben-Ari \& Kedem-Friedrich, 2000). In a longitudinal study of students from kindergarten to grade three, Bodovski and Farkas (2007) found that students who entered kindergarten with fewer mathematical skills tended to participate less actively in mathematics as indicated by teacher reports. These students learned less over the course of the four years. However, students who were most engaged in the activities since kindergarten demonstrated the most growth.

The degree to which students describe their own problem solving strategies and engage with the strategies of others is predictive of student achievement in mathematics (Vennman, Denessen, van den Akker \& van der Rijt, 2005; Warner, 2008; Webb et al., 2014). Student's detail and complexity in oral descriptions of problem solving was a predictive measurement of student achievement (Vennmen et al., 2005; Webb et al., 2014). Engagement with the mathematical ideas of other students also correlated with student mathematical learning (Ing et al., 2015; Vennman et al., 2005).

\section{Teacher Moves}


Research in the relationship between teacher moves, student engagement, and student learning indicates that while student engagement positively predicted student achievement, particular teacher moves created higher rates of student engagement, which in turn led to higher student achievement (Ing et al., 2005). Ing and colleagues identified two specific teacher moves: a) teacher eliciting student thinking and b) teacher support to engage in the ideas of other students. Eliciting student thinking is defined by the literature as instances in which teachers create opportunities for students to share strategies and ask questions. Teacher support according to Ing et al., (2005) is defined as facilitating questions and encouraging students to restate the strategies of their peers. Work by Gilles and colleagues have found that in classrooms where teachers are consistently paraphrasing student thinking, asking students for more explanations, asking challenging questions, elaborating on student ideas, generally scored overall higher on assessments of reasoning and problem solving (Gillies \& Boyle, 2008; Gillies \& Haynes, 2011; Gillies \& Khan, 2009).

Effective use of teacher moves is predicated on Mathematical Knowledge of Teaching (MKT) or developing understanding of how learners come to understand complex mathematical ideas (Hill, Rowan, \& Ball, 2005). MKT stems from the differentiation between teacher's knowledge of mathematics and the teacher's knowledge of how children learn in particular mathematical areas (Shulman, 1986). This issue of teacher training specifically in MKT is particularly relevant to the field of special education. Special education training for teachers has historically focused on understanding learner characteristics rather than focusing on content-specific pedagogy (Woodward \& Montague, 2002). According to Woodward and Montague (2002), special 
education teachers are often trained to see pedagogy as generalized strategies that work across content areas. For example, using flashcards to support memorization both for math facts and letter recognition. These generalized strategies are quite different from discipline specific strategies, such as in mathematics, that support the student's ability to build on known facts using properties of operations. Even as research in mathematics education has demonstrated the importance of MKT for effective mathematic teaching (Hill et al., 2005), little research has investigated MKT for those who teach students with disabilities (Lambert \& Tan, 2016).

\section{Learning Disabilities}

There are two models for understanding disabilities that dominate academic inquiry: a) the medical model, and b) the social model (Linton, 1998). The medical model (also known as the deficit model) defines learning disabilities as individual neurological deficits. LD is typically identified in the United States through a school-based referral process that uses a medical model approach of diagnosis and treatment. The category of LD in the US includes learners with specific difficulties in reading, writing, or mathematics. This review presents an analysis of the mathematical engagement of students with LD as defined by the regulations of the Individuals with Disabilities Education Improvement Act (2004). Thus, while some of the students may be included in the estimated $3 \%$ to $6 \%$ of the population with a mathematical disability (MD) (Mazzocco, 2007), it would be impossible to verify this using the data available in the published research reports.

While the medical model dominates research inquiry in special education, it is not the only available perspective on disability. The social model recognizes that biological 
differences exist, but considers society as the primary disabling factor (U.P.I.A.S., 1975; Linton, 1998). For example, a learning disability can be described using the medical model as a processing deficit, or through the social model as a mismatch between students with learning differences and inflexible classrooms (Reid \& Valle, 2004). Sociocultural analysis has described LD as interactional, produced through a series of iterated interactions that position the learners in relation to mathematics (Ben-Yehuda, Lavy, Linchevski \& Sfard, 2005; Heyd-Metzuyanim, 2013). Competence in mathematics itself is a feature of the engagement structures of the mathematics classroom (Gresalfi et al., 20009). Different mathematical pedagogies and engagement structures enable and disable students with LD, suggesting that ability and disability are not fixed entities but emerge in interaction with pedagogical contexts (Author, 2015).

\section{Learning Disabilities and Mathematics}

Research in mathematics learning within special education has questioned mathematics reform, particularly constructivism, which tends to be equated by special educators with discovery learning (Woodward \& Montague, 2002). One theme that emerges in special education literature is the notion that students with LD need explicit guidance to construct strategies (Jitendra, 2013). Recent studies have provided evidence that students with disabilities and low achieving students in mathematics can construct effective computational strategies independently (Peltenburg, Heuvel-Panhuizen, \& Robitzsch, 2012; Peters, De Smedt, Torbeyns, Verschaffel, \& Ghesquière, 2014; Verschaffel, Torbeyns, De Smedt, Luwel, \& Van Dooren, 2007). A second assumption is that teachers trained in constructivist and sociocultural approaches to mathematics do not ever make specific aspects of learning explicit. Research indicates the contrary, 
approaches to pedagogy using these methods document the complex and demanding role of the teacher in assisting students to generalize strategies and concepts through the design of cognitively demanding tasks and the expert facilitation of mathematical discussion (Smith \& Stein, 2011).

\section{Methods}

Taking a sociocultural perspective on mathematics learning, the integrative research review (Torraco, 2005) was designed to identify research studies that documented engagement of students labeled LD in standards-based mathematics in the natural setting of a classroom.

We began our search for articles by searching in the educational databases ERIC and JSTOR for the terms, "special education," and/or "disability", in combination with any of the following terms: "engagement", "mathematical practices," and/or "engagement," "discussion." For each article we found that met our criteria, we searched through the citations of that article, as well as identifying any research that cited these papers (using Google Scholar). We also searched through the citations in the two studies that are cited as evidence of the limited engagement of students with LD in reform mathematics (Baxter et al., 2001; Bottge et al., 2001). We read the full text of each article that was identified to determine if it met our criteria.

The criteria for inclusion included:

- Study was a peer-reviewed research report.

- Study included qualitative data about classroom engagement of students in mathematical problem-solving or discussion, such as descriptions of student engagement in small group problem-solving or discourse. 
- There was evidence that the curriculum of classroom was standards-based. Jitendra (2013), identified several key characteristics of standards-based mathematics curriculum: (a) emphasis on problem solving, (b) focus on connections between mathematical topics and real-world applications, (c) group work and mathematical discussion, and (d) beginning with studentinvented algorithms rather than standard algorithms. We included studies that met all four of these criteria.

- Study includes students with LD as identified as school records.

Many of the articles that emerged in our initial search were not included. Most of the research published in special education journals that focused on mathematics were either diagnostic, or attempting to precisely describe mathematical learning disabilities, or were interventions that were held outside of the classroom. Very few of these interventions met our criteria for standards-based mathematics, as intervention studies tended to use Direct Instruction to provide students with standardized algorithms, rather than allowing students to develop their own algorithms.

We also excluded studies because they were not sufficiently focused on students with documented Learning Disabilities, instead focused on low achieving students. Two studies included in this review used a combination of students classified as LD and low achieving (Baxter et al., 2001; Bottge et al., 2001). In this review, the authors include students of interest are identified as having an Individual Education Plans (IEPs) for LD. IEPs serve as the legal documentation in the United States that allow students to receive special education services. 
Our analysis focuses on only seven articles that met our criteria. We recognize that the small number of articles is a significant limitation of this review, yet it also reminds us how little is known about the observed engagement of students with LD in standards-based mathematics in classrooms.

Table 1 details the participants in each study. Some studies included in this review did not include information about the race of the students. This reflects a persistent issue in special education in which students are defined primarily by a disability and other aspects of their identify are de-emphasized (Artiles, 2013). All of the teachers in these studies were general education teachers.

$<$ Insert Table 1>

\section{Findings}

This literature review aimed to identify studies that explored the engagement of students with LD in standards-based mathematics classrooms. While some research studies offered evidence that students with LD were not participating equally in standards-based mathematics (Baxter et al., 2001; Baxter et al., 2005; Bottge et al., 2002), other studies offered evidence of promising practices to deepen the engagement of students with LD (Baxter et al., 2003; Bottge et al., 2007; Foote \& Lambert, 2011; Moscardini, 2010). Some of these studies offered glimpses of classrooms in which engagement in mathematical discussion and problem solving could not be predicted by whether or not a student was labeled LD.

This section is organized around three categories. First, we present findings for related to the first Mathematical Practice Standard, Making sense of problems and persisting in solving them (2010). Second, we discuss the engagement of students with 
LD in whole group mathematical discussion, critical to Mathematical Practice Standards 2 and 3. The final category analyzes the importance of Mathematical Knowledge for Teaching across the studies.

\section{Engaging Students with LD in Problem-solving}

Multi-modal curriculum design. The reviewed studies suggested that students with LD were more successful in problem-solving when curriculum is multi-modal in terms of engagement, representation, and expression. Baxter and colleagues (2001) found limited engagement in a standards-based classroom in which instruction was organized through a textbook. Bottge and colleagues (2009) asserted that the complex multi-media formats supported student learning through multiple forms of representation, encouraging students to actively engage in cognitively complex tasks. In the classrooms in which the teachers were trained in cognitively guided instruction (CGI) (Foote \& Lambert, 2011; Moscardini, 2010), students had choice about what materials they used to solve problems (equations, drawings, connecting cubes, base-ten blocks, etc.), demonstrating multiple means of expression and engagement. In CGI classrooms, students tended to use multiple means of representation to explain their thinking (Foote \& Lambert, 2011). Students in the study by Baxter et al. (2005) were more successful in explaining their mathematical thinking through writing. In all of these cases, students with LD were supported when they were able to use multiple means of representation as they solved mathematics problems.

Consistent routine. Most standards-based mathematics classrooms follow a similar problem-solving structure: the teacher launches a problem, the students solve individually or in small groups, and then the class gathers for a whole group discussion in 
which students present their solutions. Three of the authors identified the consistent routine developed around problem solving as a possible positive factor influencing the engagement of students with LD in problem-solving, as well as whole class discussion (Baxter et al., 2002; Baxter et al, 2005; Foote \& Lambert, 2011). Developing routines for complex cognitive behavior such as problem solving is beneficial for learners as it creates an external scaffold for internal processes (Collins, Brown, \& Holum, 1991).

Teacher scaffolds for problem solving. In the study by Moscardini (2010), teachers found that some students with disabilities had difficulty starting problem solving. In this study, two simple scaffolds were effective: restating the word problems (while retaining the problem type) and rereading the word problems in small chunks that students modeled step-by-step. These simple interventions have considerable promise as they reduce difficulty negotiating language but not the mathematical challenge of the task.

Equitable small group work. Studies of small group dynamics reveal that small group work can often be inequitable; students who are perceived as less successful are marginalized (Cohen, Lotan, Scarloss, \& Arellano, 1999; Esmonde \& Langer-Osuna, 2013). Baxter et al. (2001) and Bottge et al. (2001) documented that students with LD were less engaged in small group work than their peers. In the next iteration of their research, Bottge and colleagues (2007) provided additional support to the small groups, including training teachers to better support equitable engagement in these groups. They saw increased engagement in small group work after teachers were trained.

\section{Engaging Students with LD in Mathematical Discussion}


Student rehearsal of strategy shares. Baxter et al. (2005) describe how a paraprofessional working with students with LD provided the opportunity for the students to rehearse their strategy share, which may have contributed to the higher level of engagement for students with LD. Research in the engagement of students with LD in inquiry science found that individual student interviews allowed students to try out complex strategies in a supportive context, and suggested that these interviews might have allowed these students to participate more in whole-group discussion (Palinscar, Magnusson, Collins, \& Cutter, 2001).

Access to manipulatives and notebooks. In the classroom studied by Foote and Lambert (2011), students with IEPs continued to use their notebooks to support their strategy shares in whole group discussion for a longer period of time than other students, suggesting that having a record of their problem solving was particularly supportive. Students with LD uniquely used manipulatives rather than equations to represent relational thinking, or complex mathematical thinking that uses relationships between numbers to solve algebraic equations (Carpenter, Franke, \& Levi, 2003). In several instances, students with IEPs in these classrooms used connecting cubes as they presented, physically modeling their process as much as they described it verbally. The use of connecting cubes may have allowed the students to present thinking that was more mathematically sophisticated than would have been possible otherwise. Baxter and colleagues (2005) found that students with LD writing in math journals demonstrated far deeper engagement than during whole class discussion, suggesting that notebooks could be a critical support for these students. 
Teacher questioning. Several of the studies documented the importance of teacher questioning to support increased engagement in whole group discussion. Baxter et al. (2001) documented strategies that were unsuccessful in engaging students with LD. The teacher asked a focus student (chosen by drawing a name at random) "what is 11:08 minus 3 minutes"(Baxter et al., 2001, p. 536). The student shook her head, and the teacher simplified the question into " 8 minus 3" (Baxter et al., 2001, p. 536). The student answered correctly, and the teacher moved on. In the study by Foote and Lambert (2011), students with IEPS were also initially reluctant to present strategies, and also initially responded with one-word answers. However, the teacher asked multiple follow-up questions of each of the students, setting up an expectation that these students would be accountable for explanations of their strategies. Both studies were conducted in third grade classrooms, but the difference between the engagement of students labeled LD was dramatic. In the study by Baxter and Woodward (2001), the students with disabilities never offered more than one-word responses during whole-group instruction across the data available for the entire school year. By the end of the year, students with disabilities had equal rates of engagement compared to their non-disabled peers (Foote \& Lambert, 2011). This discrepancy suggests that teacher questioning moves may have a significant impact on the engagement of students with disabilities in mathematics.

Consistent routine. A consistent routine may have supported students with LD to engage in whole group discussion. Some students may take longer to understand and engage in complex tasks such as sharing mathematical strategies, documented in the study by Foote and Lambert (2011) which found a engagement gap in whole group discussion in the first half of the academic year that was eliminated in the second half. 


\section{Teacher Knowledge}

MKT refers to an in-depth professional knowledge of how children typically learn particular mathematics concepts (Hill et al., 2005). Every study that documented successful engagement of students labeled LD either included professional development for teachers in MKT, or the researchers chose teachers who were identified as experienced teachers of standards-based mathematics. Three studies (Bottge et al., 2007; Baxter et al., 2002; Moscardini, 2010) specifically mentioned that in order to support students with LD, teachers needed to have developed MKT. In other studies, this connection was implicit, as the description of teacher moves built on MKT that was developed in professional development embedded in the larger study (Foote \& Lambert, 2011).

\section{Limitations of Review and Ideas for Future Research}

This research review analyzed only seven studies that met the criteria, significantly limiting the generalizability of the findings. However, these preliminary findings are critical as they suggest directions for future research in an under-explored area of research in both mathematics and special education.

Research in the mathematical learning of students with LD must focus attention on intervention in engagement. While such research need not replace research on contentspecific interventions in mathematics for students with learning disabilities, it could

provide a much needed focus on what learners who are labeled LD can do within standards-based mathematics, rather than what they cannot do. Additional research is needed that bridges the divide between research in special education and research in mathematics education (Author, 2016). Several areas of future research are suggested by 
these findings: 1) teacher knowledge including MKT in inclusive classrooms, 2)

curriculum design, and 3) teacher moves to increase engagement and engagement that includes students with LD.

The first category of necessary research is MKT in the context of special education teachers. The studies reviewed here suggest that shifts in the training of special education teachers towards content-based approaches could allow students labeled LD greater access to successful engagement in standards-based mathematics. Research could document the current state of MKT in special educators, and interventions to deepen that knowledge. Because special education developed out of experimental psychology and behaviorism, the implicit role of the teacher is to implement interventions with fidelity (Osgood, 2008), rather than understanding the teacher as an active agent whose decisions make significant difference to learning. In addition, as special educators bring a different set of knowledge practices to the classroom, researchers could investigate which of these knowledge practices positively impact student learning, in addition to MKT.

The second area of necessary research is the design of mathematical curriculum. These studies suggest that students with LD were supported by curriculum that was responsive to student thinking, so that teachers designed the tasks based not on a predesigned sequence or textbook but on the current understandings of their students' thinking (Carpenter et al., 1999/2014). Students were supported when mathematics curriculum provided multi-modal representations of content, and multiple ways of engaging in mathematical activity. Further research should explore how curriculum organization affects engagement structures, and what the effects are for students with LD in mathematics. 
This research recommendation aligns with the Common Core Standards for Mathematics, which recommends using Universal Design for Learning (UDL) as a way to design mathematics instruction so that it benefits the widest possible group of students from the outset (CAST, 2011). In a UDL classroom, students are given access to multiple representations of content, multiple ways to engage with content, and multiple ways to express what they know. Additional research can be done using UDL design principles in mathematics classrooms, exploring how flexibility and choice can increase the engagement of students with LD in standards-based mathematics.

These studies suggest that teacher moves are critical in increasing student engagement. Leading productive mathematical discussions that include a wide range of learners is a complex instructional practice, yet has received little attention in special education or mathematics education (Baxter et al., 2002). The studies reviewed here suggest some teacher moves that were successful in including students with LD in wholegroup mathematical discussion. Additional research should explore this area in more detail. Empson (2003) explored the teacher moves of a first grade teacher who successfully included two low-achieving students in complex mathematical discussions around fractions. Similar to the teacher studied by Foote and Lambert (2011), Empson found that the teacher consistently pressed for accountability for these learners, even when their explanations were initially confusing. This teacher also engaged in individual conferences with these students, using these conferences to help her scaffold their engagement in the whole group. Additional research could document successful teacher practices for students with disabilities, including correlations between increased engagement in mathematical discussion and achievement. 


\section{Implications for Teaching and Learning}

These studies suggest that simply including students with LD in standards-based instruction is not enough. Some of the studies documented limited engagement for students with LD in standards-based mathematics without additional supports (Baxter et al., 2001; Bottge et al., 2002). However, this review has also documented classrooms in which engagement was equalized through teacher shifts in classroom practice, from including all students in whole-group discussion to equalizing small group engagement. These findings, while preliminary, offer considerable promise to both special education and general education teachers of mathematics.

Much is at stake. Students with LD require access to high-quality mathematics instruction that prepares them to meet the Common Core Standards in Mathematics. We can no longer assume that standards-based mathematics will not work for these students based on perceived deficits. Nor can we assume that simply including students with learning disabilities in standards-based mathematics classrooms will lead to higher achievement. Instead, we must learn more about how to support all learners for full engagement in standards-based mathematics classrooms. These supports are likely to be helpful for a wide range of learners, assisting teachers in making standards-based mathematics more equitable for all. 


\section{References}

ARTILES, A. J. (2013). Untangling the racialization of disabilities. Du Bois Review: Social Science Research on Race, 10(02), 329-347.

AUTHOR, 2015.

AUTHOR, 2016.

*BAXTER, J. A., WOODWARD, J. and OLSON, D. (2001). Effects of reform-based mathematics instruction on low achievers in five third-grade classrooms. Elementary School Journal, 101(5), 529 - 547.

*BAXTER, J. A., WOODWARD, J. and OLSON, D. (2005). Writing in mathematics: An alternative form of communication for academically low-achieving students. Learning Disabilities Research \& Practice, 20(2), 119-135.

*BAXTER, J., WOODWARD, J., VOORHIES, J. and WONG, J. (2002). We talk about it, but do they get it? Learning Disabilities Research and Practice, 17(3), 173-185.

BEN-ARI, R., \& KEDEM-FRIEDRICH, P. (2000). Restructuring heterogeneous classes for cognitive development: Social interactive perspective. Instructional Science, 28(2), 153167.

BEN-YEHUDA, M., LAVY, I., LINCHEVSKI, L. and SFARD, A. (2005). Doing wrong with words: What bars students' access to arithmetical discourses. Journal for Research in Mathematics Education, 36(3), 176-247. http://doi.org/10.2307/30034835

BOALER, J. (1997). Experiencing school mathematics: Traditional and reform approaches to teaching and their impact on student learning. Mahwah, NJ: Lawrence Erlbaum. 
BOALER, J. and STAPLES, M. (2008). Creating mathematical futures through an equitable teaching approach: The case of Railside School. The Teachers College Record, 110(3), $608-645$.

BOALER, J., WILIAM, D. and BROWN, M. (2000). Students' experiences of ability grouping: Disaffection, polarization and the construction of failure. British Educational Research Journal, 26(5), 631-648. http://doi.org/10.1080/713651583

BODOVSKI, K. and FARKAS, G. (2007). Mathematics growth in early elementary school: The roles of beginning knowledge, student engagement, and instruction. The Elementary School Journal, 108(2), 115-130. http://doi.org/10.1086/525550

BOTTGE, B. A. (1999). Effects of contextualized math instruction on problem solving of average and below-average achieving students. Journal of Special Education, 33(2), 8192.

BOTTGE, B. A., HEINRICHS, M., CHAN, S. and SERLIN, R. C. (2001). Anchoring adolescents' understanding of math concepts in rich problem-solving environments. Remedial \& Special Education, 22(5), 299.

*BOTTGE, B. A., HEINRICHS, M., MEHTA, Z. D. and YA-HUI HUNG. (2002). Weighing the benefits of anchored math instruction for students with disabilities in general education classes. Journal of Special Education, 35(4), 186.

*BOTTGE, B. A., RUEDA, E., SERLIN, R. C., HUNG, Y.H., and KWON, J. M. (2007). Shrinking achievement differences with anchored math problems: Challenges and possibilities. Journal of Special Education, 41(1), 31-49.Carpenter, T. P., Fennema, E. Franke, M. L., Levi, L., Empson, S. B., \& Lindquist, M. M. (1999/2014). Children's 
mathematics: Cognitively guided instruction (2 edition). Portsmouth, NH: Heinemann Press.

CARPENTER, T. P., FRANKE, M. L. and LEVI, L. (2003). Thinking mathematically: Integrating arithmetic and algebra in elementary school. Portsmouth, NH: Heinemann Press.

CAST. (2011). Universal Design for Learning Guidelines version 2.0. Wakefield, MA:uthor. COHEN, E. G., LOTAN, R. A., SCARLOSS, B. A. and ARELLANO, A. R. (1999). Complex instruction: Equity in cooperative learning classrooms. Theory into Practice, 38(2), 8086.

COLLINS, A., BROWN, J. S. and HOLUM, A. (1991). Cognitive apprenticeship: Making thinking visible. American Educator, 6(11), 38-46.

DUNN, C., RABREN, K. S., TAYLOR, S. L. and DOTSON, C. K. (2012). Assisting students with high-incidence disabilities to pursue careers in science, technology, engineering, and mathematics. Intervention in School and Clinic, 48(1), 47-54.

EMPSON, S. B. (2003). Low-performing students and teaching fractions for understanding: An interactional analysis. Journal for Research in Mathematics Education, 305-343.

ESMONDE, I. and LANGER-OSUNA, J. M. (2013). Power in numbers: Student engagement in mathematical discussions in heterogeneous spaces. Journal for Research in Mathematics Education, 44(1), 288-315.

*FOOTE, M. Q., \& LAMBERT, R. (2011). I have a solution to share: Learning through equitable engagement in a mathematics classroom. Canadian Journal of Science, Mathematics and Technology Education, 11(3), 247-260.

http://doi.org/10.1080/14926156.2011.595882 
FORMAN, E. A. (1996). Learning mathematics as engagement in classroom practice:

Implications of sociocultural theory for educational reform. Theories of Mathematical Learning, 115-130.

GILLIES, R. M. and BOYLE, M. (2008). Teachers' discourse during cooperative learning and their perceptions of this pedagogical practice. Teaching and Teacher Education, 24(5), $1333-1348$.

GILLIES, R. M. and HAYNES, M. (2011). Increasing explanatory behavior, problem solving, and reasoning within classes using cooperative group work. Instructional Science, 39(3), $349-366$.

GILLIES, R. M. and KHAN, A. (2009). Promoting reasoned argumentation, problem-solving and learning during small-group work. Cambridge Journal of Education, 39(1), 7-27.

GRESALFI, M., MARTIN, T., HAND, V. and GREENO, J. (2009). Constructing competence: an analysis of student engagement in the activity systems of mathematics classrooms. Educational Studies in Mathematics, 70(1), 49-70.

HEYD-METZUYANIM, E. (2013). The co-construction of learning difficulties in mathematics - teacher-student interactions and their role in the development of a disabled mathematical identity. Educational Studies in Mathematics, 83(3), 341-368. http://doi.org/10.1007/s10649-012-9457-z

HILL, H. C., ROWAN, B. and BALL, D. L. (2005). Effects of teachers' mathematical knowledge for teaching on student achievement. American Educational Research Journal, 42(2), 371-406.

INIDIVIDUALS WITH DISABILITIES EDUCATION, 20 U.S.C. $§ 1400$ (2004) 
ING, M., WEBB, N. M., FRANKE, M. L., TURROU, A. C., WONG, J., SHIN, N. and FERNANDEZ, C. H. (2015). Student engagement in elementary mathematics classrooms: the missing link between teacher practices and student achievement? Educational Studies in Mathematics, 1-16. http://doi.org/10.1007/s10649-015-9625-

JACKSON, H. G. and NEEL, R. S. (2006). Observing mathematics: Do students with EBD have access to standards-based mathematics instruction? Education and Treatment of Children, 29(4), 593.

JITENDRA, A. K. (2013). Understanding and accessing standards-based mathematics for students with mathematics difficulties. Learning Disability Quarterly, 36(1), 4-8. http://doi.org/10.1177/0731948712455337

KURZ, A., ELLIOTT, S. N., WEHBY, J. H. and SMITHSON, J. L. (2010). Alignment of the intended, planned, and enacted curriculum in general and special education and its relation to student achievement. Journal of Special Education, 44(3), 131-145.

LAVE, J. and WENGER, E. (1991). Situated learning: Legitimate peripheral engagement. Cambridge, England: Cambridge University Press.

LINTON, S. (1998). Claiming disability: Knowledge and identity. New York, NY: NYU Press.

MAZZOCCO, M. M. (2007). Defining and differentiating mathematical learning disabilities and difficulties. In Why is math so hard for some children; the nature and origins of mathematical learning difficulties and disabilities. Baltimore, Maryland: Paul H. Brookes. 
MOSCARDINI, L. (2009). Tools or crutches? Apparatus as a sense-making aid in mathematics teaching with children with moderate learning difficulties. Support for Learning, 24(1), 35-41. http://doi.org/10.1111/j.1467-9604.2009.01395.x

*MOSCARDINI, L. (2010). “I like it instead of maths": How pupils with moderate learning difficulties in Scottish primary special schools intuitively solved mathematical word problems. British Journal of Special Education, 37(3), 130-138. http://doi.org/10.1111/j.1467-8578.2010.00461.x

MOSCARDINI, L. (2013). Primary special school teachers' knowledge and beliefs about supporting learning in numeracy. Journal of Research in Special Educational Needs, 15(1), 37-47. http://doi.org/10.1111/1471-3802.12042

NASIR, N. S. and HAND, V. M. (2006). Exploring sociocultural perspectives on race, culture, and learning. Review of Educational Research, 76(4), 449-475.

NASIR, N. S. and HAND, V. (2008). From the court to the classroom: Opportunities for engagement, learning, and identity in basketball and classroom mathematics. The Journal of the Learning Sciences, 17(2), 143-179.

NATIONAL GOVERNORS ASSOCIATION CENTER FOR BEST PRACTICES and COUNCIL of CHIEF STATE SCHOOL OFFICERS (2010). Common Core State Standards Initiative | The Standards | Mathematics. Washington, DC: National Governors Association Center for Best Practices, Council of Chief State School Officers. Retrieved from http://www.corestandards.org/the-standards/mathematics

OSGOOD, R. L. (2008). The history of special education: A struggle for equality in American public schools. NY: New York: Greenwood Publishing Group. 
PALINSCAR, A. S., MAGNUSSON, S. J., COLLINS, K. M. and CUTTER, J. (2001).

Making science accessible to all: Results of a design experiment in inclusive classrooms. Learning Disability Quarterly, 24(1), 15-32.

PELTENBURG, M., HEUVEL-PANHUIZEN, M. and van den ROBITZCH, A. (2012). Special education students' use of indirect addition in solving subtraction problems up to 100-A proof of the didactical potential of an ignored procedure. Educational Studies in Mathematics, 79(3), 351-369. http://doi.org/10.1007/s10649-011-9351-0

PETERS, G., De SMEDT, B., TORBEYNS, J., VERSCHAFFEL, L. and GHESQUIÈRE, P. (2014). Subtraction by addition in children with mathematical learning disabilities. Learning and Instruction, 30, 1-8.

REID, D. K. and VALLE, J. (2004). The discursive practice of learning disability: Implications for instruction and parent school relations. Journal of Learning Disabilities, $37(6), 466-481$.

SHULMAN, L. S. (1986). Those who understand: Knowledge growth in teaching. Educational Researcher, 4-14.

SILVER, E. A. and STEIN, M. K. (1996). The Quasar Project: The "revolution of the possible" in mathematics instructional reform in urban middle schools. Urban Education, $30(4), 476-521$.

SMITH, M. S. and STEIN, M. K. (2011). 5 practices for orchestrating productive mathematics discussions. Reston, VA; Thousand Oaks, CA: National Council of Teachers of Mathematics.

TORRACO, R. J. (2005). Writing integrative literature reviews: Guidelines and examples. Human Resource Development Review, 4(3), 356-367. 
UNION of PHYSCIALLY IMPAIRED AGAINST SEGREGATION. (1975). Fundamental principles of disability. London, England: U.P.I.A.S.

VENNMAN, S., DENESSEN, E., van den AKKER, A., \& VAN DER RIJT, J. (2005). Effects of a cooperative learning program on the elaborations of students during help seeking and help giving. American Educational Research Journal, 42(1), 115-151.

VERSCHAFFEL, L., TORBEYNS, J., De SMEDT, B., LUWEL, K. and Van DOOREN, W. (2007). Strategy flexibility in children with low achievement in mathematics. Educational and Child Psychology, 24(2), 16-27.

WARNER, L. B. (2008). How do students' behaviors relate to the growth of their mathematical ideas? The Journal of Mathematical Behavior, 27(3), 206-227.

WEBB, N. M., FRANKE, M. L., DE, T., CHAN, A. G., FREUND, D., SHEIN, P. and MELKONIAN, D. K. (2009). "Explain to your partner": teachers' instructional practices and students' dialogue in small groups. Cambridge Journal of Education, 39(1), 49-70.

WEBB, N. M., FRANKE, M. L., ING, M., WONG, J., FERNANDEZ, C. H., SHIN, N. and TURROU, A. C. (2014). Engaging with others' mathematical ideas: Interrelationships among student engagement, teachers' instructional practices, and learning. International Journal of Educational Research, 63, 79-93. http://doi.org/10.1016/j.ijer.2013.02.001

WOODWARD, J. and BAXTER, J. (1997). The effects of an innovative approach to mathematics on academically low-achieving students in inclusive settings. Exceptional Children, 63(3), 373-388.

WOODWARD, J. and MONTAGUE, M. (2002). Meeting the challenge of mathematics reform for students with LD. Journal of Special Education, 36(2), 89-101. 
Table 1. Participants and Curriculum in Reviewed Studies

\begin{tabular}{|c|c|c|c|c|c|c|}
\hline Study & & Student Part & cipants & & & Curriculum \\
\hline & $\begin{array}{l}\text { Grade } \\
\text { Level }\end{array}$ & $\begin{array}{l}\mathrm{N} \text { (focus } \\
\text { students) }\end{array}$ & $\begin{array}{l}\text { Disability } \\
\text { Status }\end{array}$ & $\begin{array}{l}\text { Race or } \\
\text { Language } \\
\text { Status }\end{array}$ & Gender & \\
\hline $\begin{array}{c}\text { Baxter et } \\
\text { al. (2001) }\end{array}$ & 3 & 16 & $\begin{array}{l}7 \text { LD, } 9 \\
\text { LA }\end{array}$ & $\begin{array}{l}\text { No } \\
\text { information }\end{array}$ & $\begin{array}{l}\text { No } \\
\text { information }\end{array}$ & $\begin{array}{l}\text { Everyday } \\
\text { Mathematics }\end{array}$ \\
\hline $\begin{array}{l}\text { Baxter et } \\
\text { al. (2002) }\end{array}$ & 4 & 3 & $\begin{array}{l}1 \mathrm{LD}, 2 \\
\mathrm{LA}\end{array}$ & $\begin{array}{l}\text { No } \\
\text { information }\end{array}$ & $\begin{array}{l}1 \text { female, } 2 \\
\text { male }\end{array}$ & $\begin{array}{l}\text { Everyday } \\
\text { Mathematics }\end{array}$ \\
\hline $\begin{array}{l}\text { Baxter et } \\
\text { al. (2005) }\end{array}$ & 7 & 4 & 4 IEPs & $\begin{array}{l}\text { No } \\
\text { information }\end{array}$ & $\begin{array}{l}2 \text { female, } 2 \\
\text { male }\end{array}$ & $\begin{array}{l}\text { Teacher- } \\
\text { created } \\
\text { problem- } \\
\text { solving } \\
\text { routine } \\
\end{array}$ \\
\hline $\begin{array}{l}\text { Bottge et } \\
\text { al. (2002) }\end{array}$ & 7 & 8 & $\begin{array}{l}\text { All LD or } \\
\text { ED }\end{array}$ & $\begin{array}{l}\text { No } \\
\text { information } \\
\text { about focus } \\
\text { students, } \\
\text { but } \\
\text { majority of } \\
\text { students in } \\
\text { entire study } \\
\text { were } \\
\text { Caucasian }\end{array}$ & $\begin{array}{l}\text { No } \\
\text { information }\end{array}$ & $\begin{array}{l}\text { Enhanced } \\
\text { Anchored } \\
\text { Instruction }\end{array}$ \\
\hline $\begin{array}{l}\text { Bottge et } \\
\text { al. }(2007)\end{array}$ & 7 & 3 & LD & $\begin{array}{l}1 \text { African- } \\
\text { American, } \\
12 \\
\text { Caucasian }\end{array}$ & $\begin{array}{l}\text { All focus } \\
\text { students } \\
\text { male }\end{array}$ & $\begin{array}{l}\text { Enhanced } \\
\text { Anchored } \\
\text { Instruction }\end{array}$ \\
\hline $\begin{array}{l}\text { Foote \& } \\
\text { Lambert } \\
(2011)\end{array}$ & 3 & 3 & LD & $\begin{array}{l}3 \text { African- } \\
\text { American }\end{array}$ & $\begin{array}{l}1 \text { female, } 2 \\
\text { male }\end{array}$ & $\begin{array}{l}\text { Teacher- } \\
\text { created } \\
\text { algebra } \\
\text { routine } \\
\text { (Carpenter } \\
\text { et al., 2002) }\end{array}$ \\
\hline $\begin{array}{l}\text { Moscardi } \\
\text { ni (2010) }\end{array}$ & $\begin{array}{l}\text { Primary } \\
\text { aged } \\
\text { students }\end{array}$ & 24 & LD & $\begin{array}{l}\text { No } \\
\text { information }\end{array}$ & $\begin{array}{l}\text { No } \\
\text { information }\end{array}$ & $\begin{array}{l}\text { Teacher- } \\
\text { created } \\
\text { problem- } \\
\text { solving } \\
\text { routine } \\
\text { (Carpenter } \\
\text { et al., } \\
\text { 1999/2014). }\end{array}$ \\
\hline
\end{tabular}


Table 2. Findings

\begin{tabular}{|c|c|c|}
\hline Study & Findings around engagement & $\begin{array}{l}\text { What supported increased } \\
\text { engagement }\end{array}$ \\
\hline $\begin{array}{l}\text { Baxter et al. } \\
(2001)\end{array}$ & $\begin{array}{l}\text { - Limited achievement growth for } \\
\text { LD/LA students } \\
\text { - Limited engagement for focus } \\
\text { students in whole group discussion } \\
\text { or small group work }\end{array}$ & \\
\hline $\begin{array}{l}\text { Baxter et al. } \\
(2002)\end{array}$ & $\begin{array}{l}\text { - Growth in engagement of focus } \\
\text { students from week } 3 \text { to week } 9 \text { in } \\
\text { whole group discussion }\end{array}$ & $\begin{array}{l}\text { - MKT of teacher } \\
\text { - Teacher facilitation of } \\
\text { discourse } \\
\text { - Consistent problem-solving } \\
\text { routine } \\
\text { - Paraprofessional supported } \\
\text { engagement through } \\
\text { rehearsal }\end{array}$ \\
\hline $\begin{array}{l}\text { Baxter et al. } \\
(2005)\end{array}$ & $\begin{array}{l}\text { - Limited engagement for focus } \\
\text { students in whole group discussion } \\
\text { - Much deeper engagement for focus } \\
\text { students through writing journals }\end{array}$ & $\begin{array}{l}\text { - Multi-modal curriculum } \\
\text { - MKT of teacher }\end{array}$ \\
\hline $\begin{array}{l}\text { Bottge et al. } \\
(2001)\end{array}$ & $\begin{array}{l}\text { - Limited engagement for focus } \\
\text { students in whole group discussion } \\
\text { or small group work. }\end{array}$ & \\
\hline $\begin{array}{l}\text { Bottge et al. } \\
(2007)\end{array}$ & $\begin{array}{l}\text { - Growth in engagement and } \\
\text { achievement of focus students }\end{array}$ & $\begin{array}{l}\text { - Multi-modal curriculum } \\
\text { - MKT of teacher } \\
\text { - Explicit attention to equitable } \\
\text { engagement in small groups. }\end{array}$ \\
\hline $\begin{array}{l}\text { Foote \& } \\
\text { Lambert } \\
(2011)\end{array}$ & $\begin{array}{l}\text { - Initially an engagement gap in } \\
\text { whole group discussion between } \\
\text { focus students and other students. } \\
\text { - Engagement gap was eliminated by } \\
\text { the end of the academic year. } \\
\text { - Focus students demonstrated } \\
\text { growth in conceptual knowledge } \\
\text { through presentations }\end{array}$ & $\begin{array}{l}\text { - Multi-modal curriculum } \\
\text { - MKT of teacher } \\
\text { - Teacher facilitation of } \\
\text { discourse } \\
\text { - Consistent problem solving } \\
\text { routine }\end{array}$ \\
\hline $\begin{array}{l}\text { Moscardini } \\
(2010)\end{array}$ & $\begin{array}{l}\text { Focus students were able to solve } \\
\text { word problems successfully } \\
\text { without prior explicit instruction. }\end{array}$ & $\begin{array}{l}\text { - Multi-modal curriculum } \\
\text { - MKT of teacher } \\
\text { - Teacher facilitation of } \\
\text { discourse } \\
\text { - Teacher designed problems } \\
\text { were responsive to students. }\end{array}$ \\
\hline
\end{tabular}


